\title{
Hemolytic Anemia Presenting as Hemoglobinuria from Intentional Paradichlorobenzene Mothball Ingestion
}

\author{
Mary Ondinee U. Manalo, ${ }^{1}$ Cherie Grace G. Quingking ${ }^{2}$ and Carissa Paz C.Dioquino ${ }^{2}$ \\ ${ }^{1}$ Department of Medicine, College of Medicine and Philippine General Hospital, University of the Philippines Manila \\ ${ }^{2}$ National Poison Management and Control Center, University of the Philippines-Philippine General Hospital
}

\begin{abstract}
A 24-year-old Filipino male was diagnosed with hemolytic anemia when he presented with abrupt onset of anemia, hemoglobinuria, and increased bilirubins, after intentionally ingesting mothballs containing paradichlorobenzene. He was transfused with six units of packed red blood cells (PRBC) and was discharged improved. Paradichlorobenzene, a known oxidant, causes denaturation and precipitation of hemoglobin. These precipitates form Heinz bodies within the erythrocytes that are removed by the reticuloendothelial system, fragmenting cells to produce hemolysis. This is the first reported case in the Philippines of hemolytic anemia from paradicholorobenzene ingestion as confirmed by the UP-National Poison Management and Control Center.
\end{abstract}

Key Words: mothballs, paradicholorobenzene, 2,4-dichlorobenzene, hemolytic anemia, methemoglobinemia

\section{Introduction}

Mothballs could be made of naphthalene, paradichlorobenzene, or camphor. Differentiation among mothballs is difficult because they may have similar odors and are all white, crystalline solids at room temperature. Paradichlorobenzene is commonly found here in the Philippines as a component of toilet deodorant blocks, but mothballs sold on the streets may contain this chemical as well. Between naphthalene and paradicholorobenzene, the latter is the less common component of mothballs and the

Presented at the 10th Scientific Congress of the Asia Pacific Association of Medical Toxicology, November 12-14, 2011, Penang, Malaysia.

Paper won First Place at the UP-PGH Department of Medicine Research Forum Case Report Category, September 2011, UP-PGH Guazon Hall.

Paper won Best Poster at the Philippine College of Physicians Annual Convention, May 2011, SMX Convention Center.

Paper was a Finalist at the UP-PGH Research Week Case Report Category, November 2011, UP-PGH Science Hall.

Corresponding author: Mary Ondinee U. Manalo, MD

Department of Medicine

Philippine General Hospital

University of the Philippines Manila

Taft Avenue, Ermita, Manila 1000 Philippines

Telephone: 0923-6503548

Email: marymanalo_md@yahoo.com less acutely toxic of the two. However, like naphthalene, it has also been known to induce hemolytic anemia because it possesses one benzene ring. ${ }^{1}$ We report a case of a man who intentionally ingested three mothballs made of paradicholorobenzene who experienced severe hemolytic anemia that necessitated blood transfusion.

\section{Case}

A 24-year-old male inmate from Manila was admitted for persistent vomiting three days after ingestion of three crushed mothballs.

Three days prior to admission, the patient intentionally swallowed three crushed mothballs. After an hour, he experienced nausea and vague abdominal pain. A day prior to admission, he presented with persistent vomiting and passed out dark stools. Eight hours prior to admission, vomiting became more frequent and was now associated with coffee-ground material. Abdominal pain became more intense as well. He was then brought to the Emergency Room of the Philippine General Hospital for consultation.

The patient presented at the emergency room awake but weak-looking, tachypneic but with otherwise stable vital signs. He was complaining of severe abdominal pain. He had icteric sclerae, dry oral mucosa, and epigastric tenderness. Chest, cardiovascular, and digital rectal examination was unremarkable. He was complaining of severe abdominal pain. A nasogastric tube was inserted and this evacuated coffee-ground gastric secretions. Since he came in 3 days post-ingestion, administration of activated charcoal had no value.

Since the most notorious complication of mothball poisoning is methemoglobinemia, a filter paper test to screen for this was done and it turned out to be positive. A mothball sample from the same packaging was retrieved and floatation test was performed. The sinking of the mothball in hypertonic saline and its somewhat oily appearance favored that the mothball was made of paradicholorobenzene. Initial hemoglobin was normal at 120 $\mathrm{mg} / \mathrm{dL}$ with a normal reticulocyte count. Peripheral blood smear revealed normocytic, normochromic anemia with slight poikilocytosis and no toxic granulations. Prothrombin time and activated partial thromboplastin time were normal. Coomb's test was negative. 
On the patient's second hospital day, he passed bright red urine. Fresh frozen plasma (FFP) was transfused. On urinalysis, the patient's urine tested positive for hemoglobin with minimal intact red blood cells. The toxicologic plan at this time was to assess for ongoing blood loss and to prevent further gastrointestinal bleeding. Since paradicholorobenzene acts as an oxidative stressor in glycolysis, ascorbic acid was administered as an antioxidant.

On the patient's third hospital day, hemoglobinuria progressed despite transfusion of blood products. Hemoglobin also dropped to $89 \mathrm{mg} / \mathrm{dL}$. Vomiting of coffeeground material persisted as well. On the patient's fifth hospital day, he complained of extreme weakness, dizziness, and irritability. There was also deepening icterus of the sclerae. Digital rectal examination was unremarkable. Coffee-ground vomiting resolved during this time. A complete blood count was then requested and hemoglobin went down to $53 \mathrm{mg} / \mathrm{dL}$ (from an initial level of $120 \mathrm{mg} / \mathrm{dL}$ ), with a high reticulocyte count. Blood transfusion was hastened. At this time, the assessment of the toxicology service was hemolytic anemia from paradicholorobenzene ingestion on the basis of 1) abrupt onset of anemia; 2) hemoglobinuria; 3) high reticulocyte count, $\mathrm{LDH}, \mathrm{TB}, \mathrm{DB}, \mathrm{IB}$; and 4 ) a history of ingestion of a known oxidant. Figure 1 and Table 1 explain the symptoms of the patient.

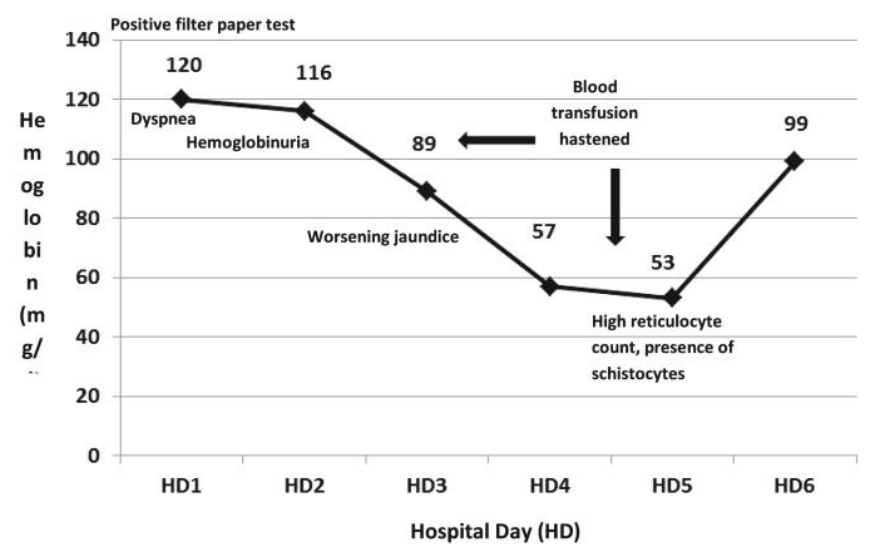

Figure1. Hospital course of the patient with the corresponding hemoglobin levels per day.

On his eighth hospital day, the patient was discharged well after six units of PRBC and eight units of FFP. He was seen by the Psychiatry service prior to discharge and was given liaison and supportive psychotherapy. The patient was discharged on ferrous sulfate plus folic acid tablets to be taken for three months.

On follow-up, the jaundice had resolved. His complete blood count was within normal range. A blood sample was then extracted to screen for glucose-6-phosphate dehydrogenase deficiency to rule out other possible causes of hemolytic anemia, but his enzyme level was within the normal range for his age. At the time of this writing, the patient is waiting for his case to be reviewed, but has no suicidal ideations. He is optimistic about his future.

Table 1. Signs and symptoms experienced by the patient. The laboratory examinations that were done, the corresponding medical conditions, and treatments are also listed.

\begin{tabular}{|c|c|c|c|}
\hline $\begin{array}{c}\text { Signs/ } \\
\text { Symptoms }\end{array}$ & Test & Medical Condition & Treatment \\
\hline Dyspnea & $\begin{array}{l}\text { Filter paper test: } \\
(+) \text { muddy brown blood } \\
\text { compared with control } \\
\text { ABG: }\end{array}$ & Methemoglobinemia & $\begin{array}{c}\text { High flow } \\
\text { oxygen } \\
\text { Methylene blue } \\
\text { Ascorbic acid }\end{array}$ \\
\hline $\begin{array}{l}\text { Pallor, } \\
\text { jaundice, } \\
\text { bright red } \\
\text { urine, } \\
\text { weakness }\end{array}$ & $\begin{array}{c}\text { Low oxygen saturation } \\
\text { Urinalysis: } \\
\text { (+) Hemoglobinuria } \\
\text { CBC: } \\
\text { Abrupt onset of anemia, } \\
\text { high reticulocyte count, } \\
\text { (+) schistocytes } \\
\text { Blood chemistry: } \\
\text { High LDH, TBDBIB }\end{array}$ & Hemolytic anemia & $\begin{array}{c}\text { Blood } \\
\text { transfusion, } \\
\text { decontamination } \\
\text { or removal of the } \\
\text { source of } \\
\text { hemolysis }\end{array}$ \\
\hline
\end{tabular}

\section{Discussion}

Mothballs in the Philippines could contain naphthalene, paradicholorobenzene, or camphor. Most that are sold in groceries and hardware stores contain naphthalene because it is cheaper and sublimates more slowly. However, those that are sold on the streets and which are imported from other countries are unlabeled, and could contain any of the three compounds.

Identifying the composition of these unlabeled mothballs presents a problem to physicians. Fortunately, they can be differentiated using bedside tests. ${ }^{2}$ Table 2 is used widely by toxicologists and emergency physicians alike. It has been validated and has a specificity of $91 \%$ according to one study, if at least two of the tests are positive. Also, according to an article from the Annals of Emergency Medicine, these tests are (1) simple to perform, (2) provides an answer in seconds to minutes, and (3) is definitive enough to eliminate the need for costly additional testing at an analytical reference laboratory. These tests have the advantage that the endpoints are dramatic and the reagents are commonly available. ${ }^{3}$

Table 2. Comparison of the different physical characteristics of mothballs (Source: Toxicology Compendium by Leikin and Paloucek, 2008, p. 828).

\begin{tabular}{lccc}
\hline & PDB & Naphthalene & Camphor \\
\hline Physical & Wet and oily & Dry & Wet or dry \\
Water & Sink & Sink & Float \\
4 oz water +3 & Sink & Float & Float \\
heaping tsp of salt & & & \\
Drop of turpentine & Soluble & Moderately soluble & - \\
Heating & Green color & No color & - \\
\hline
\end{tabular}


In the patient's case, the tests suggested that he ingested paradicholorobenzene, a less common component of mothballs. Paradichlorobenzene (PDB) is 1,4dichlorobenzene (IUPAC name) with the chemical formula of $\mathrm{C}_{6} \mathrm{H}_{4} \mathrm{Cl}_{2}$ and a molecular weight of $177 \mathrm{~g} / \mathrm{mol}$. The molar mass of PDB is the key to the floatation test which is the easiest to perform at bedside. The PDB mothball sinks while naphthalene floats because the latter is less dense, having a molar mass of only $128.17 \mathrm{~g} / \mathrm{mol}^{4,5}$

PBD is an aromatic hydrocarbon, an industrial precursor/intermediate, an organochloride, and pesticide. It is mainly used as a component of mothballs, deodorant blocks in restrooms, garbage cans, and animal-holding facilities, and insecticide in fruits and tobacco seeds. ${ }^{6}$

It is rapidly absorbed through the lungs and gastrointestinal tract. Absorption is more rapid in the oral route than by inhalation. Dermal absorption is slow. ${ }^{7}$ Oral absorption is complete while it is only $20 \%$ absorbed via inhalation. $^{2}$ It is mainly metabolized via oxidation in the liver to the main metabolite 2,5-dichlorophenol and distributed throughout the body and stored in the adipose, kidney, liver, and blood. ${ }^{7}$ Excretion is primarily renal and biliary. ${ }^{2}$ Clearance rates and half-lives of PDB are not dosedependent. Half-life is 10.12 hours. The acute oral LD 50 is $>500 \mathrm{mg} / \mathrm{kg}^{7}$

Various toxicities manifest as cerebellar ataxia, allergic purpura, dermal burns, edema, hyperpigmentation, hemolysis, methemoglobin formation, granuloma development, hepatitis, hepatic necrosis with cirrhosis, eye irritation, and glomerulonephritis. ${ }^{2}$ The hepatotoxicity and nephrotoxicity observed in laboratory animals are likely due to the formulations of toxic intermediates formed while converting 1,4-PDB to 2,5-dichlorophenol by cytochrome P450, by depletion of glutathione at higher doses, or both. ${ }^{8}$

Since PDB exerts an oxidative stress on the red blood cell, a bedside test was performed to screen for methemoglobin. The positive filter paper test in the patient meant the presence of at least $15 \%$ methemoglobin. This abnormal hemoglobin is formed when the iron atom in hemoglobin loses one electron to an oxidant, and the ferrous $\left(\mathrm{Fe} 2^{+}\right)$state of iron is transformed into the ferric $\left(\mathrm{Fe}^{+}\right)$state. Although methemoglobin is always present at low concentrations in the body, methemoglobinemia is defined herein as an abnormal elevation of methemoglobin. Signs and symptoms typically associated with different methemoglobin concentrations are shown in Table 3.

Hemoglobin will transport an $\mathrm{O}_{2}$ molecule only when its iron atom is in the reduced or ferrous state. ${ }^{2}$ Excessive methemoglobin disrupts oxygen delivery to tissues and this unoxygenated form of hemoglobin explains why the blood of the patient was muddy brown instead of the usual bright red, and this was seen in the filter paper test performed at the emergency room. Oxidized iron can be reduced nonenzymatically using ascorbic acid as the electron donor, but this is slow and quantitatively less important. ${ }^{1}$ This was the antidote used in our patient because of its availability, but methylene blue is the gold standard in the treatment of methemoglobinemia. Figure 2 shows the different pathways involved in the reduction of methemoglobin.

Table 3. Signs and symptoms typically associated with methemoglobin concentrations in healthy patients with normal hemoglobin concentrations (Source: Goldfrank's Manual of Toxicologic Emergencies, 2007, p982).

\begin{tabular}{ll}
\hline $\begin{array}{c}\text { Methemoglobin Concentration } \\
(\mathbf{\%})\end{array}$ & \multicolumn{1}{c}{ Signs and Symptoms } \\
\hline $1-<3$ (Normal) & None \\
$3-15$ & Possibly none \\
& Slate gray cutaneous coloration \\
& Pulse oximeter will read a low $\mathrm{SaO}_{2}$ \\
$15-19$ & Cyanosis \\
& Chocolate brown blood \\
$20-49$ & Dyspnea \\
& Exercise intolerance \\
& Headache \\
& Fatigue \\
& Dizziness, syncope \\
& Weakness \\
& Tachypnea \\
& Metabolic acidosis \\
$50-69$ & Dysrhythmias \\
& Seizures \\
& CNS depression \\
& Coma \\
& Grave hypoxic symptoms \\
& Death \\
\hline
\end{tabular}

Hemolysis and methemoglobinemia are both caused by oxidant stress, and hemolysis can occur following episodes of methemoglobinemia. Oxidants damage the erythrocyte at different locations in different entities. Hemolysis occurs when oxidants damage the hemoglobin chain acting directly, causing denaturation and precipitation of the protein. These precipitates form Heinz bodies within the erythrocytes that are removed by the reticuloendothelial system, fragmenting cells to produce hemolysis. ${ }^{1,2}$

Hemolysis is far more frequently reported and is more severe in naphthalene exposure. This is because PDB contains only one benzene ring while naphthalene consists of two benzene rings. It has been hypothesized that this benzene ring intercalates between the bonds of normal hemoglobin and causes its destruction. ${ }^{1}$

On literature review, we found only two case reports that dealt with hemolysis after ingestion of PDB. The first was of 3-year-old child who presented with acute onset of jaundice and anemia. Exhaustive work-up after a week at the Birmingham Children's Hospital revealed methemoglobinemia, negative Coomb's, RBC fragility, and no enzyme deficiencies. Upon admission, it was considered that the child was probably suffering from an acute hemolytic anemia secondary to an infectious cause. However, workup was negative. Enquiries were then 


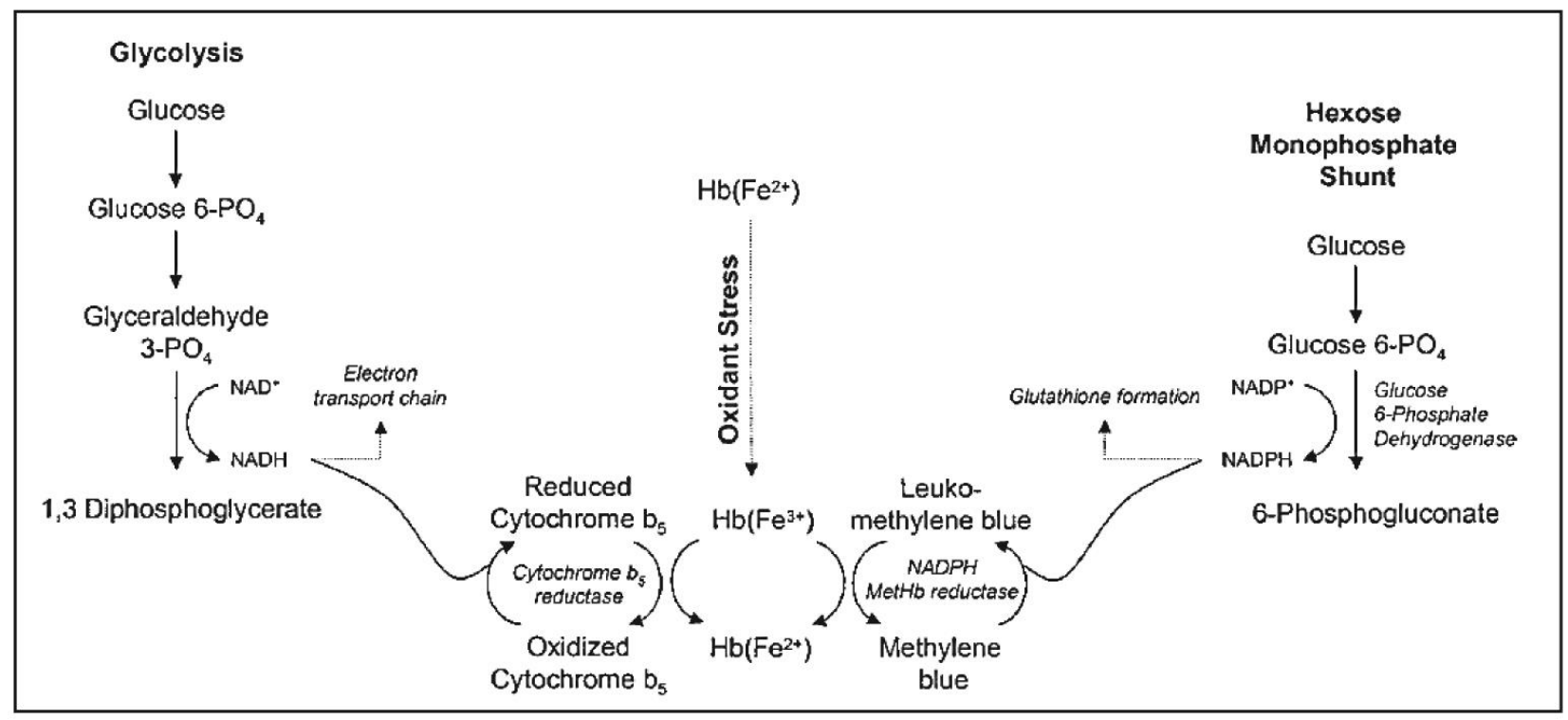

Figure 2. Role of glycolysis in the Embden-Meyerhof pathway and the role of methylene blue in the reduction of methemoglobin. Quantitatively the most important reductive system requires nicotinamide adenine dinucleotide (NADH). Within the red cell, another enzyme uses nicotinamide-adenine dinucleotide phosphate (NADPH) to reduce methemoglobin but this pathway plays a relatively minor role in methemoglobin reduction under normal circumstances. When NADPH methemoglobin reductase system is provided with an exogenous electron carrier such as methylene blue, this system is accelerated and becomes the primary method of detoxification. (Source: Goldfrank's Manual of Toxicologic Emergencies, 2007, p978).

directed toward poisons and drugs. His mother then revealed that the child had been playing with a small canister labeled as "Demothing Crystals". These crystals, which contain PDB, had been given away with a vacuum cleaner that was purchased some months ago. Urine examination revealed the metabolite 2,5-dichlorophenol. The patient was given mega doses of ascorbic acid and was transfused with blood components. He was discharged well. ${ }^{9}$

The other case report was of an asymptomatic boy who presented at the pediatric emergency department after ingesting paradichlorobenzene mothballs. The patient was not given any antidote during that time and was sent home. Three days after the ingestion, the boy returned with hemolysis and mild methemoglobinemia. ${ }^{10}$

Hemolytic effects of paradicholorobenzene in man are mostly extrapolated from the same effects from benzene and naphthalene. Benzene is a recognized hemolytic agent and its toxicity has been reported as early as 1938 when industrial workers handling benzene experienced chronic hemolytic anemia. Whereas there is paucity in data regarding $\mathrm{PDB}$, its more common counterpart, which is naphthalene, has been documented in several case reports describing hemolysis from ingestion and inhalation. ${ }^{11}$

Treatment for overdose if with concomitant methemoglobinemia consists of high-flow oxygen and administration of medicinal grade methylene blue or high doses of ascorbic acid. The patient should also be decontaminated if received early. Emesis should be stimulated if received within 30 minutes or lavaged with activated charcoal if within one hour. Milk and oils increase absorption and must be avoided. Decontamination should be instituted in cases of dermal exposures. ${ }^{4}$ Supportive treatment consists of transfusion of the appropriate blood products. Since direct contact of PDB with the mucosa can cause bleeding, gastrointestinal signs may be addressed with proton pump inhibitors, $\mathrm{H}_{2}$-blockers, or sucralfate. The prognosis is favorable if the clinical signs are treated and if the patient does not have an underlying kidney or liver disease. $^{12}$

Hemolytic anemia is a very rare and often delayed complication of PDB ingestion (possibly inhalation as well since it has been reported from naphthalene). A high index of suspicion is the key to catching these patients, especially if they do not present as suicide attempts. In the patient's case, the serial complete blood counts that were performed caught the hemolytic anemia in its early state and prevented high output failure. Anticipatory care cannot be overemphasized.

\section{Conclusion}

A case of hemolytic anemia initially presenting as hemoglobinuria after ingestion of mothballs made from paradicholorobenzene was reported. Bedside screening tests on how to identify the component of mothballs were 
presented as well. The hemolytic presentation of PDB ingestion was delayed, severe, and complete. With supportive care and blood transfusions, complete recovery occurred.

\section{Significance}

The UP National Poison Management and Control Center receives at most only three cases of mothball poisoning every year. ${ }^{13}$ This is because mothballs are difficult to ingest compared with liquid toxins. According to the Fertilizer and Pesticide Authority, mothballs which are registered in the Philippines are only made from naphthalene. There is no law that monitors repackaged and unlabeled insecticides which are sold on the streets. There is also no law that requires repackaged insecticides to indicate their active ingredients. As confirmed by the UP National Poison Management and Control Center, this is the first confirmed case of hemolytic anemia from paradicholorobenzene ingestion in the Philippines.

Aside from mothballs, paradicholorobenzene is more commonly found in the Philippines as the main ingredient of toilet deodorant blocks. These are freely available to the public and are sold in vast quantities each year. The importance of keeping these out of the reach of children cannot be overemphasized; especially toilet deodorizers which are commonly hung underneath the toilet sink or adjacent to the toilet bowl and are readily within children's reach. These are also easily accessible to patients with red cell membrane defects who are prone to hemolysis.

\section{Recommendations}

This report was submitted to the Department of Health and the Food and Drug Authority with a recommendation to impose appropriate warnings on all products that contain paradicholorobenzene. We have also communicated with the Newborn Screening Reference Center of the National Institutes of Health to include paradichlorobenzene in their official list of chemicals to avoid so that they could include this in their official handout given to parents with children diagnosed with G6PD deficiency.

${ }^{*}$ This case report was made in collaboration with the UP National Poison Management and Control Center. For inquiries on mothball poisoning, you may call the Poison Control hotline at 025241078 or 02-5548400 loc 2311 or visit us at Ward 14A of the Philippine General Hospital.

\section{References}

1. Hoffman RS, Nelson LS, Howland MA, et al. Goldfrank's Manual of Toxicologic Emergencies, The Clinical Basis of Medical Toxicology. New York: McGraw-Hill; 2002. pp. 977-985.

2. Leikin JB, FP Paloucek. Poisoning and Toxicology Handbook, $4^{\text {th }}$ ed. New York: Informa Health Care, Inc; 2008. pp. 875-876.

3. Ambre J, Ruo TI, Smith-Coggins R. Mothball composition: three simple tests for distinguishing paradichlorobenzene from naphthalene. Ann Emerg Med. 1986; 15(6):724-6.

4. Winkler JV, Kulig K, Rumack BH. Mothball differentiation: naphthalene from paradichlorobenzene. Ann Emerg Med. 1985; 14(1):30-2.

5. Paradichlorobenzene Technical Fact Sheet by the National Pesticide Information Center [Online]. 2007 [cited Jan 2007]. Available from www.npic.orst.edu.

6. Toxicology Card for 1,4-dichlorobenzene (T30159) Version 1.0 from the Toxin, Toxin-Target Database [Online]. 2010 [cited Dec 2010]. Available from www.t3db.org.

7. 1,4-Dichlorobenzene from the Technology Transfer Network Air Toxics Web Site of the U.S. Environmental Protection Agency [Online]. 2000 [cited Dec 2010]. Available from www.epa.gov.

8. Hissinik AM, Dunnewijk R, van Ommen B, van Bladeren PJ. Kinetics and metabolism of 1,4-dichlorobenzene in male Wistar rats: no evidence for quinone metabolites. Chem Biol Interact. 1997; 103(1):17-33.

9. Hallowell M. Acute haemolytic anemia following the ingestion of paradichlorobenzene. Arch Dis Child. 1959; 34(173):74-7.

10. Sillery JJ, Lichenstein R, Barrueto F Jr, Teshome G. Hemolytic anemia induced by ingestion of paradichlorobenzene mothballs. Pediatr Emerg Care. $2009 ; 25(4): 252-4$.

11. Toxicological profile for dichlorobenzene by the U.S. Department of Health and Human Services, Agency for Toxic Substances and Disease Registry [Online]. 2006 [cited March 2006]. Available from www.atsdr.cdc.gov/toxprofiles.

12. De Clementi C. Moth repellant toxicosis. Toxicology Brief: Vet Med. 2005; 100:24-28.

13. Census of the UP-National Poison Management and Control Center (2005-2010). 